\title{
Physical and Chemical Characteristic of Halal Gelatin Extracted from Buffalo Hide with Addition of Pineapple Rind at Different Ratio
}

\author{
Aprizal $^{1}$, Irdha Mirdhayati $^{1}$, Yendraliza $^{2}$ \\ ${ }^{1}$ Post Harvest Laboratory, Faculty of Agriculture and Animal Science, Universitas Islam Negeri Sultan \\ Syarif Kasim, Pekanbaru, 28293, Indonesia \\ ${ }^{2}$ Biology and Reproduction Laboratory, Faculty of Agriculture and Animal Science, Universitas Islam \\ Negeri Sultan Syarif Kasim, Pekanbaru, 28293, Indonesia \\ Correspondent email: mirdhayati@gmail.com
}

\begin{abstract}
The production of halal gelatin from buffalo hide waste, which came from an animal being slaughtered according to Islamic law, by adding pineapple rind as an extraction agent was an alternative to produce halal gelatin. The availability of buffalo hide in Riau Province is stable and its hide has high protein content. This research was conducted to produce and determine the characteristics of halal gelatin from buffalo hide using solution of pineapple skin in terms of their physical and chemical properties. The Completely Randomized Design (CRD) was the experimental design used with consist of 3 treatments and 4 replications. The treatment was ratio hide: pineapple rind solution, namely 3:1, 3:2, 3:3 w/v. The parameters observed were yield, viscosity, color, $p H$, ash content and moisture content. The results showed that immersion of buffalo hide in the solution of pineapple rind at different ratio gave highly significant increased the viscosity and ash content of gelatin but not significant effect to yield percentage, color, $\mathrm{pH}$ and moisture of gelatin. The yield percentage ranging from 5.99-7.33\%, $\mathrm{pH} 4.83-$ 4.85, viscosity was 1.95-2.20 cP, color 0.54-0.71 absorbance unit, ash 0.25-, 032\% and moisture 9.97-9.99\%. It can be concluded that the best treatment was ratio 3:2 and 3:3 according to had viscosity, pH, color, ash and moisture in line with the standard of gelatin by Gelatin Manufacture Institute of America (GMIA).
\end{abstract}

Keywords: buffalo hide, chemical properties, halal gelatin, pineapple rind, waste

\section{Introduction}

Indonesia is one of the importing gelatin countries. The problem that arises was not of all imported gelatin was produced by halal procedure due to origin of hide material and the animal slaughtering techniques that were not accordance with Islamic law. The production of halal gelatin from buffalo hide waste, which came from an animal being slaughtered according to Islamic law, by adding pineapple rind as an extraction agent was an alternative to produce halal gelatin.

The availability of buffalo hide is high in Riau Province because there are three regencies which have the highest number of registered slaughtered cattle, i.e. buffalo, namely: Kampar Regency, Kuantan Singingi Regency and Pekanbaru city. According to Badan Pusat Statistik of Riau Province 2017, the number of slaughtered of buffalo in 2015 at Kampar Regency was 7,797 heads, in Kuantan Singingi Regency was 782 heads and in Pekanbaru City was 731 heads. According to Badan Pusat Statistik of Riau Province 2017, the number of slaughtered buffalo in 2015 at Kampar Regency was 7,797 heads, in Kuantan Singingi Regency was 782 heads and in Pekanbaru City was 731 heads. As a result, hide is available as the by-product of buffalo slaughtering. Processing buffalo hide into gelatin is one of the ways to increase the added value of hide.

Raw skin is divided into two groups, namely the group of hide derived from large animals such as cattle, buffaloes, horses, known as hide, and the group of skin derived from small animals such as goats, rabbits, and reptiles, known as skin. The hide from large animal has more protein content than the skin of small animals (Rafika et al., 2016).

Gelatin is a product derived from extraction of collagen, bone and other tissues by using acids, bases or enzymatic process (GMIA, 2012). According to Remawati (2016), the gelatin derived bovine hide that extracted by acetic acid $0.2 \mathrm{M}$ had value of viscosity $30 \mathrm{cP}$, yield was $6.29 \%$, pH value was 5.6, water content $63.51 \%$, and ash content was $0.3 \%$. Mulyani et al., (2017) had studied on gelatin producing from buffalo hide by using different acid solution (hydrochloric acid, citric acid and acetic acid) at various concentrations. The produced yield percentages were $6.22 \%, 6.52 \%$ and $6.79 \%$, respectively. The research on gelatin producing from buffalo hide waste by using pineapple rind extract has not been reported, so this research is urgent to conduct.

According to Kumaunang (2011), the pineapple rind contains bromelain enzymes about 0.07 Unit $/ \mathrm{ml}$. 
Bromelain is protease enzyme which has the properties of hydrolyzing proteins (Dubey et al., 2012). Protease enzymes will break up the peptide bonds of collagen proteins (Suhermiyati \& Setyawati, 2008).

The production of pineapple in Riau Province in 2015 was 74.389 ton (BPS Riau Province, 2017). The high production of pineapple in Riau Province also produces high pineapple rind, which can be used as a source of crude bromelain. This pineapple rind could use to extract gelatin from buffalo hide. This research was conducted to produce and determine the characteristics of halal gelatin from buffalo hide using solution of pineapple rind in terms of their physical and chemical properties.

\section{Materials and methods}

The material used in this research was $7 \mathrm{~kg}$ buffalo hide from the traditional slaughterhouse in Bangkinang. The slaughtering method must be according to Islamic law. The pineapple rind came from traders on Jalan Rimbo Panjang, Kampar and distilled water.

The research method was the experiment with Completely Randomized Design (CRD) as experimental design with 3 treatments and 4 replications. The treatment was the ratios hide: pineapple rind solution, namely $3: 1,3: 2$ and $3: 3 \mathrm{~g} / \mathrm{v}$. The parameters observed were yield, viscosity, color, $\mathrm{pH}$, ash content and moisture content.

\subsection{Preparation of hide}

The preparation of buffalo hide were conducted as follow : The buffalo hide was cleaned by using water and then continued to remove the hair by burning it with smal fire on the surface of hide. This process aimed to removed the lipid in the hide. Then, the hide was cut in to small cubes (size of 2-4 cm) and finally, the small cubes were rinsed by the water repeatedly until clean.

\subsection{Preparation of pineapple rind extract}

The preparation of pineapple rind extract was carried out as follows: the waste of pineapple rind was cleaned from dirt by using water. Then, the pineapple rind was cut into small pieces. The pieces of rind and distilled water were put into a blender with a ratio of $1: 1$ and followed by grinding for about 5 minutes. Furthermore, the pineapple rind juice was filtered by gauze to get the filtrate of pineapple rind. Then, this filtrate was dissolved in distilled water according to the ratio in the treatment.

\subsection{Process of gelatin extraction}

Procedure of gelatin extraction from buffalo hide were carried out as follows: an amount of $300 \mathrm{~g}$ of the cleaned hide was soaked in the pineapple rind extract according the research treatment (ratio of buffalo hide: solution of pineapple rind extract, namely P1 300:100, P2 300:200 and P3 300:300 w/v). Amount of distilled water were added in P1 and P2 were $200 \mathrm{ml}$ and 100 $\mathrm{ml}$, respectively. Percentages of pineapple rind extract were added in the treatment respectively about $33.33 \%$ (P1), $66.67 \%$ (P2) and $100 \%$ (P3). The soaking process was held at room temperature in about 20 hours. Then, hide was rinsed by distilled water. The extraction process was began by placing the hide in a glass jar and adding $1000 \mathrm{ml}$ of distilled water, then heating it in a shaker waterbath at $70^{\circ} \mathrm{C}$ for 2 hours. The gelatin solution will be produced from this heating process. The gelatin solution was then filtered to separate the gelatin solution and buffalo hide. The next process was placing the gelatin solution in the refrigerator until gelatin became hardening. Then, the hard gelatin was dried using an oven at $105^{\circ} \mathrm{C}$ for 24 hours. Then the dried gelatin was ground using a blender and was sieved until it formed flour.

\subsection{The parameter observed}

The parameter observed in this research were physical and chemical properties of gelatin. The physical properties were analysis of yield percentage (GMIA, 2013), viscosity (GMIA, 2013), color (Schrieber \& Gareis, 2007). The chemical properties were $\mathrm{pH}$ value (GMIA, 2013), moisture (AOAC, 2005), and ash content (AOAC, 2005).

\subsection{Data Analysis}

Data statistically analyzed by analysis of variance to know the effect of the treatment towards the parameter observed. If the treatment showed significant effect, it will be continued to post hoc analysis by Duncan Multiple Range Test (DMRT) at $\alpha 0.05$.

\section{Result and discussion}

The pineapple rind extract contains proteolytic enzyme, known as bromelain. The activity of crude enzyme in the pineapple rind extract in this research was $0.071-0.076 \mathrm{unit} / \mathrm{ml}$. This enzyme activity was similar to the research of Kumaunang et.al. (2011), the enzyme activity in pineapple rind solution was 0.071 unit $/ \mathrm{ml}$.

\subsection{Physical properties (Yield percentage, viscosity, color)}

Data on yield percentage, viscosity and color of gelatin from buffalo hide that was soaked in pineapple rind extract at different ratios were shown in Table 1. The analysis of variance showed that the treatment of buffalo hide and pineapple rind extracts at different ratio had significant effect on increasing the viscosity of gelatin but did not significantly affect the yield percentage and the color of gelatin. DMRT analysis showed that gelatin made with buffalo hide and pineapple rind extract at ratio $3: 2$ and $3: 3$ had significantly higher viscosity than gelatin made from buffalo hide and pineapple rind extract at ratio 3:1. This means that the increase of concentration 
pineapple rind extract from $33.33 \%$ to $66.67 \%-100 \%$ can increase the viscosity of gelatin.

The increasing of viscosity related to increasing of gelatin concentration at ratio $3: 2$ and $3: 3$ of buffalo hide and pineapple rind extract as an effect from proteolytic activity of bromelain enzyme in the pineapple rind extract. But, both of ratios could not give the increasing of yield percentage of gelatin significantly. This indicated that the concentration of pineapple rind extract should be greater and ratio of hide and pineapple rind extract should be varied in order to improve the yield percentage of gelatin.

Table 1. Physical properties of halal gelatin from different ratio of Buffalo hide and pineapple rind extract

\begin{tabular}{lc}
\multicolumn{1}{c}{ Experiment } & Value (unit) \\
\hline Yield Percentage & $5.99 \pm 2.02 \%{ }^{\mathrm{ns}}$ \\
\hline $3: 1$ & $8.69 \pm 1.57 \%^{\mathrm{ns}}$ \\
$3: 2$ & $7.33 \pm 1.36 \%^{\mathrm{ns}}$ \\
$3: 3$ & \\
\hline Viscosity & $1.95 \pm 0.02 \mathrm{cP}^{\mathrm{a}}$ \\
\hline $3: 1$ & $2.14 \pm 0.11 \mathrm{cP}^{\mathrm{b}}$ \\
$3: 2$ & $2.20 \pm 0.14 \mathrm{cP}^{\mathrm{b}}$ \\
$3: 3$ & \\
\hline Color & $0.54 \pm 0.01 \mathrm{au}{ }^{\mathrm{ns}}$ \\
\hline $3: 1$ & $0.65 \pm 0.05 \mathrm{au}^{\mathrm{ns}}$ \\
$3: 2$ & $0.71 \pm 0.02 \mathrm{au}^{\mathrm{ns}}$ \\
$3: 3$ & Note: different superscript in the same column showed \\
significant effect $(\alpha 0.05)$, ns showed not significant effect. \\
Data was shown as mean \pm standard deviation.
\end{tabular}

The yield percentage of gelatin in this research was similar to the yield percentage of gelatin from buffalo hide which was soaked in pineapple solution for 12-96 hours, which result the yield percentage about 5.29$6.20 \%$ (Gozali, 2018). This research emphasized that soaking time for 20 hours could produce the yield percentage of gelatin similar to soaking time for 96 hours, and both of fruit and rind of pineapple extract showed similar enzymatic activity in hydrolysis of buffalo hide.

The similar phenomenon also reported by Mulyani et al. (2017) that the yield percentage of gelatin did not significantly increased when buffalo hide was soaked in a different acid (hydrochloric citric, and acetic acids at concentrations of $0.3,0.6,0.9,1.2$, and $1.5 \mathrm{M}$, respectively). The yield percentage ranged from 6.30$29.27 \%$. Another research by Kurnia (2015) reported that the soaking of bone of bovine head in $5 \%$ hydrochloric acid solution for 10, 15 and 20 days did not significantly affect the increase yield percentage, and gave the percentage $6.22 \%, 6.52 \%$ and $6.79 \%$, respectively.

Viscosity was a measure of the physical properties of gelatin which is strongly related to gel strength. Viscosity analysis was done to determine the level of viscosity of gelatin as a solution at certain concentrations and temperatures (GMIA, 2013). The viscosity of gelatin in this research was higher than viscosity of gelatin from beef hide that was soaked in hydrogen chloride acid at $3 \%$ and $5 \%$, which showed the maximum viscosity of $1.79 \mathrm{cP}$ (Rapika et al., 2016). The value of the viscosity of this research met the gelatin standards by GMIA (2012) which are 1.5$7.5 \mathrm{cP}$.

Color of gelatin in this research was measured by using spectrophotometer and was reported in absorbance unit. The color of gelatin ranging from $0.54,0.65,0.71$ absorbance unit. The color of gelatin produced was yellowish. According to GMIA (2012), the color of gelatin depends on two factors. First, the nature of the raw material used and source of the gelatin represents a color (skin, or bone), and second, extraction process of gelatin. Gelatin from pork skin have less color than those made from bone or hide of cattle (beef, buffalo, horse). Furthermore, color does not influence the properties of gelatin or reduce its functions. The standard of color of gelatin was less color - yellow. The color of gelatin from buffalo hide in this research was yellowish and match with GMIA (2012)

\subsection{Chemical properties}

Data on $\mathrm{pH}$ value, moisture and ash content of gelatin from buffalo hide that was soaked in pineapple rind extract at different ratios were shown in Table 2. The analysis of variance showed that the treatment of buffalo hide and pineapple rind extracts at different ratio had no significant effect on the $\mathrm{pH}$ value and moisture of gelatin but had significant effect to increasing ash content of gelatin. DMRT analysis showed that gelatin were made of buffalo hide and pineapple rind extract at ratio $3: 2$ and $3: 3$ had significantly higher ash content than gelatin made from buffalo hide and pineapple rind extract at ratio 3:1. This means that the concentration increase of pineapple rind extract can increase the ash content of gelatin. The ash content of gelatin was influenced by material processing (GMIA, 2012). At higher concentrations of pineapple rind, the mineral of pineapple rind diffuse to buffalo hide during soaking at beginning of gelatin processing. The mineral content of pineapple rind also contributes in ash content of gelatin. According to Romelle et al. (2016), the pineapple rind had ash content about $4.39 \%$, calcium $8.30 \mathrm{mg} / 100 \mathrm{~g}$, zinc $6.46 \mathrm{mg} / 100 \mathrm{~g}$, iron 25.52 $\mathrm{mg} / 100 \mathrm{~g}$ and manganese $5.32 \mathrm{mg} / 100 \mathrm{~g}$. According to GMIA (2012), the ash content of gelatin varies on the type of raw material and the method of processing. Pork skin gelatins contain small amounts of chlorides or sulfates. On the other hand, gelatin from bone and hide of cattle contain primarily calcium salts of those acids which are used in the neutralization after liming. The ash content of gelatin in this research was lower than those from Mulyani et al. (2017). The ash content of gelatin from buffalo hide was soaked in a different acid (hydrochloric, citric, and acetic acids at 
concentrations of $0.9,0.5$, and $1.5 \mathrm{M}$ ) with values of $0.56 \%, 0.62 \%$ and $2.67 \%$, respectively.

The $\mathrm{pH}$ value of gelatin in this study was not affected by concentrations of pineapple rind extract. However, the $\mathrm{pH}$ value of gelatin met GMIA standards for type A gelatin, ranged from 3.8-5.5 (GMIA, 2012) and in line with the Indonesian National Standard. The moisture of gelatin in this research met the moisture standard in GMIA, ranged from $8-13 \%$. The moisture of gelatin in this research was differ than those from Mulyani et al. (2017). The moisture of gelatin from buffalo hide was soaked in a different acid (hydrochloric, citric, and acetic acids at concentrations of $0.9,0.5$, and $1.5 \mathrm{M}$ ) with values of $7.08 \%, 4.41 \%$ and $11.09 \%$, respectively.

Table 2. Chemical properties of halal gelatin from different ratio of Buffalo hide and pineapple rind extract

\begin{tabular}{cc}
\hline Experiment & Value (unit) \\
\hline $\mathrm{pH}$ & \\
\hline $3: 1$ & $4.83 \pm 0.05^{\mathrm{ns}}$ \\
$3: 2$ & $4.83 \pm 0.10^{\mathrm{ns}}$ \\
$3: 3$ & $4.85 \pm 0.17^{\mathrm{ns}}$ \\
\hline Moisture & \\
\hline $3: 1$ & $9.97 \pm 0.11 \%^{\mathrm{ns}}$ \\
$3: 2$ & $9.96 \pm 0.15 \%^{\mathrm{ns}}$ \\
$3: 3$ & $9.99 \pm 0.18 \%^{\mathrm{ns}}$ \\
\hline Ash & \\
\hline $3: 1$ & $0.25 \pm 0.04 \%^{\mathrm{a}}$ \\
$3: 2$ & $0.30 \pm 0.01 \%^{\mathrm{b}}$ \\
$3: 3$ & $0.32 \pm 0.02 \%^{\mathrm{b}}$ \\
\hline
\end{tabular}

Note: different superscript in the same column showed significant effect ( $\alpha$ 0.05), ns showed not significant effect.

\section{Conclusion}

The pineapple rind extract has a good potential as hydrolysis agent of buffalo hide at the ratios of buffalo hide and the pineapple extract $3: 2$ and $3: 3$ since it could produce halal gelatin with viscosity, color, $\mathrm{pH}$ value, moisture and ash content that meet with gelatin standard, GMIA. This research recommended the next research to increase the concentration of pineapple rind and improve ratio of buffalo hide and pineapple rind extract variety in order to increase the yield percentage of gelatin produced.

\section{References}

AOAC. Association of Official Analytical Chemists. (2005). Official Methods of Analysis. Association of Official Analytical Chemists, Inc. Arlington. Virginia,USA.

BPS. Badan Pusat Statistik Provinsi Riau. (2017). Provinsi Riau dalam Angka 2017. Retrieved January 2, 2018 from http://riau.bps.go.id.
Dubey, R., Reddy, S., \& Murthy, N. Y. S. (2012). Optimizing of Activity of Bromelain. Asian Journal of Chemistry, 24(4), 1429-1431. www.asianjournalofchemistry.co.in.

GMIA. Gelatin Manufacture Institute of America. (Revised January 2012). Gelatin Handbook. Members of the GMIA. http://www.gelatingmia.com.

GMIA. Gelatin Manufacture Institute of America. (2013). Standard Testing Methods for Edible Gelatin. Official Procedure of the GMIA, Inc. (Revised July 2013). http://www.gelatingmia.com.

Gozali, R. (2018). Sifat Fisik Geatin dari Kulit Kerbau dengan Lama Perendaman Berbeda dalam Larutan Buah Nanas. Skripsi. Program Studi Peternakan, Universitas Islam Negeri Sultan Syarif Kasim Riau. Pekanbaru.

Kumaunang, M. (2011). Aktivitas Enzim Bromelin dari Ekstrak Kulit Nenas (Anenas Comosus). Jurnal Ilmiah Sains Program Studi Kimia FMIPA. Universitas Sam Ratulangi, Manado. 11(2). http://ejournal.unsrat.ac.id

Kurnia, S.G. (2015). Kualitas Fisik Kimia dan Gelatin Tulang Kepala Sapi dengan Lama Perendaman yang Berbeda Menggunakan Asam Klorida. Skripsi. Program Studi Peternakan. Universitas Islam Negeri Sultan Syarif Kasim Riau. Pekanbaru.

Mulyani, S., Setyabudi, F. M. C. S., Pranoto, Y. \& Santoso. U. (2017). Physicochemical Properties of Gelatin Extracted from Buffalo Hide Pretreated with Different Acids. Korean Journal Food Science Animal Resources. 37(5), 708-715.

Rapika, Zulfikar \& Zumarni. (2016). Kualitas Fisik Gelatin Hasil Ekstraksi Kulit Sapi dengan Lama Perendaman dan Konsentrasi Asam Klorida (HCL) yang Berbeda. HCL 3\% dan 5\%. Jurnal Peternakan. 13(1), 829-8729.

Remawati. (2016). Ekstraksi dan Karakteristik Gelatin dari Kulit Sapi Menggunakan Metode Hidrolisis Asam. Skripsi. Fakultas Kedokteran dan Ilmu Kesehatan. Universitas Islam Negeri Syarif Hidayatullah. Jakarta.

Romelle, F. D., Ashwini, R. P., Manohar, R. S. (2016). Chemical Composition of Some Selected Fruit Peels. European Journal of Food Science \& Technology. 4(4), 12-21. www.eajournals.org.

Suhermiyati. S. \& Setyawati, S. J. (2008). The Potency of Pineapple Waste to Increase the Quality of Tuna Fish Waste for Poultry feedstuffs. Animal Production. 10(3), 174-17. 